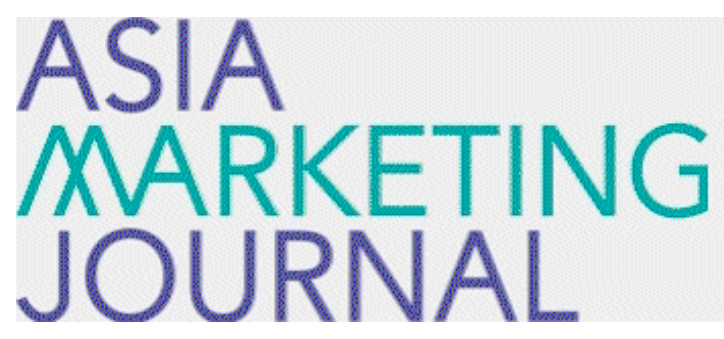

ASIA MARKETING JOURNAL

Volume 16 | Issue 2

Article 2

7-30-2014

\title{
Impact of Pursuing Goals on Customer Channel Preference
}

Dao Sheng Li

Hyun Joung Lee

Jin Hwan Hong

Follow this and additional works at: https://amj.kma.re.kr/journal

Part of the Marketing Commons

\section{Recommended Citation}

Li, Dao Sheng; Lee, Hyun Joung; and Hong, Jin Hwan (2014) "Impact of Pursuing Goals on Customer Channel Preference," Asia Marketing Journal: Vol. 16 : Iss. 2 , Article 2.

Available at: https://doi.org/10.53728/2765-6500.1538

This Article is brought to you for free and open access by Asia Marketing Journal. It has been accepted for inclusion in Asia Marketing Journal by an authorized editor of Asia Marketing Journal. 


\title{
Impact of Pursuing Goals on Customer Channel Preference: Mediating Effects of Product Utility and Process Utility
}

\author{
Dao-sheng $\mathrm{Li}^{*}$ \\ Hyunjoung Lee** \\ Jinhwan Hong***
}

This paper explores the influence of pursuing goals on customer channel preference in Chinese rural market. With the rapid change in distribution channels and increase in multi-channels, it is necessary to understand the preference for channel choice as well as product choice. This study empirically validated the conceptual framework of the relationship between the pursuing goals and customer channel choice proposed by Balasubramanian, Raghunathan, and Mahajan (2005). Based on the survey data of 232 fertilizer customers in Chinese rural market, this study explores how economic, social, and psychological pursuing goals can impact customer channel preference by mediating variables of product utility and process utility.

The results indicate that pursuing goals positively related with product utility and process utility, and product / process utility can mediate the relationship between pursuing goals and customer channel preference positively. Consequently, we can conclude that customers' economic-socialpsychological pursuing goals can directly influence customer channel preference via their purchase process utility and product utility. This result also implies that product utility is effective on process utility during consumer's buying decision making, and process utility and product utility are not mutually independent. Therefore, purchase process utility is a "latent driving force" on customer's channel choice decision.

Key words: Pursuing Goals, Customer Channel Preference, Product Utility, Process Utility, Chinese Rural Market

Assistant Professor, Department of Logistics, Linyi University(greatleer@163.com), 1st author

** Research Professor, Convergence \& Technology Management, Yonsei University(mktbridge@gmail.com)

*** Assistant Professor, Department of Business Administration, The University of Suwon(jinhongs@naver.com),

corresponding author 


\section{Introduction}

Customers exhibit complex shopping behaviors in today's emerging multichannel environment, since substantive changes have taken place in the marketing channel domain. However, the dominant distribution channel model does not reflect this phenomenon. This interpretation of the channel selection decision by the firm has its origins in the managerialist perspective on channel design which originates in the work of Aspinwall (1962). With market, product, organizational, and intermediary factors determining the choice of channel, the likelihood of a deterministic and unique relationship between product type and channel format is high. Later models of channel selection based on transactions costs (Rangan, Corey, \& Cespedes, 1993) tend to imply a similar degree of determinism in channel choice. These approaches ignore customer issues such as the frequency and size of purchases and fail to take the degree of product complexity into consideration. No approach explicitly considers variations in customer attitudes or preferences. To a large degree, the implicit assumption is that the choice of channel is generally a logical corollary of choice of product. Where customer choice has been investigated, it typically is in relation to choice of outlet within a given channel type and refers to store choice (e.g., Engel, Blackwell, \& Miniard, 1990). However, customers now face not only a choice among different channels, but also a preference within the different channels. Therefore, with the rapid change in distribution channels and increase in multi-channels, it is necessary to understand the preference for channel choice as well as product choice.

This study endeavors to find answers to the following questions: i) how does customers' pursuing goals (i.e., economic goals, self-affirmation, symbolic meaning, social influence/experiential impact and shopping schemas/scripts) impact their product utility and process utility, ii) how do customers' product utility and process utility influence customer channel preference and choice?

Balasubramanian, Raghunathan, and Mahajan (2005) present a conceptual framework of the relationship between the pursuing goals and customer channel choice in consumer goods market. However, they do not focus the framework on industrial goods, especially in emerging markets. Extending their framework, this study examines the case of industrial goods in different settings in emerging markets. We select fertilizer products in the Chinese rural market as a research subject, because fertilizer is widely bought and used by a large number of customers in the Chinese rural market. 


\section{Literature Review}

\subsection{Customers' pursuing goals}

Consumer behavior is often depicted as purposeful and goal oriented, and researchers pay attention to motivational issues in general and consumers' goals in particular (e.g. Bagozzi, \& Warshaw, 1990; Huffman \& Houston, 1993). To motivate themselves and others, individuals often attend to goals and achieving them (Heath, Larrick, \& Wu, 1999; Higgins, 1987). When individuals consider the goals they achieve by pursuing the action, their intentions to pursue that activity should rise. However, other unintended consequences might also arise from attending to goals. Such unintended consequences may further influence the pursuit of the activity beyond forming intentions (Fishbach \& Choi, 2012).

Customers pursue diverse goals when they make purchase decisions. Balasubramanian et al. (2005) focus on five goals that customers pursue while shopping: (a) pure economic goals - how consumers' pursuit of efficiency and utility can influence channel choices, (b) selfaffirmation - how the opportunity to play out their subjectively perceived expertise can influence channel choices, (c) the quest for symbolic meaning - how the satisfaction consumers anticipate from the effort and attention they expend on shopping can influence channel choices, (d) the quest for socialization and experiential impact - how consumers' need to be part of social milieus or of stimulating environments can influence channel choices, and (e) the use of shopping-related schemas and scripts - how the goal of maintaining regularity and familiarity can influence channel choices.

But Balasubramanian et al. (2005) only outline a conceptual framework that clarifies the utilities that consumers using a channel derive from both the purchase process and purchased products, and the mutual influences between these process and product utilities, and did not test how the consumers' pursuing goals affects consumer channel choice by empirical study. What's more, their research only focuses on the alternative between traditional channels and online shopping (one kind of direct marketing channel), and they do not analyze how process and product utilities influence channel choice.

\subsection{Product utility and Process utility}

Product utility can be defined as the usefulness of a product in response to the expectations of the customers or users. It is the measure of the characteristics of a product provided to meet the customers' requirements. Since product utility is designed to show details of customer requirements, and how they are satisfied by characteristics of the product (Harding, Popplewell, Fung, Richard, \& Omar, 
2001), we can understand product utility as product characteristics.

Though economics is usually outcome- oriented, it is often argued that processes matter as well. Utility is not only derived from outcomes, but also from the way outcomes are accomplished (Brouwer, Exel, Berg, Bos, \& Koopmanschap, 2005). It has been argued that people are motivated by issues of "process utility." That is, they value certain procedures for obtaining outcomes more than other procedures - i.e., they care about the procedures through which outcomes are generated. These procedural evaluations are linked to judgments about the fairness or unfairness of the procedures, leading to the psychological concept of procedural justice, or from an economic perspective "process utility" (Tyler, 2006). Brouwer et al. (2005) test the existence of process utility and the hypothesis that informal caregivers derive utility not only from the outcome of informal care, but also from the process of providing informal care. Further, Tyler (2006) explores the range and robustness of the motivational power of process utility by examining its importance in the case of help-seeking from service providers.

\subsection{Consumer channel preference (choice)}

Today's customers can access multiple consumer distribution channels. To remain competitive, retailers must offer different contact points to consumers (Oppewal, Tojib, \& Louvieris, 2013). Multi-channel strategies have become a standard approach to reach customers (Verhoef, Neslin, \& Vroomen, 2007) because consumers have become multi-channel shoppers as a consequence of a decline in channel loyalty (Gensler, Dekimpe, \& Skiera, 2007). Those actions not only include the object that you want to buy, but also the channel preference. In fact, consumers show complex purchase behaviors in the emerging multichannel environment, which includes traditional retail stores and the direct channel (Alba, Lynch, Weitz, Janiszewski, Lutz, \& Sawyer, 1997; Peterson, Balasubramanian, \& Bronnenberg, 1997). Therefore, Balasubramanian et al. (2005) believe that some consumers may rely on different channels at different stages of shopping within a single category. Research that focuses specifically on consumers' use of multiple channels in searching for and deciding on products is relatively sparse. In an early analysis, Peterson et al. (1997) conceptualized how customers might navigate a mix of catalog, internet, and traditional retail channels during various stages of the purchase process. Alba et al. (1997) analyzed the strengths and weaknesses of the various channels and noted that the presence of multiple channels can help customers efficiently shape their consideration sets early in the search process.

But how and why the customers choose the marketing channel and what they do has not been studied in-depth. Li and Hong (2013) 
suggest how and why Chinese farmers choose the direct marketing channel and what they do during their purchase process in the Chinese fertilizer market, but they do not consider other channel styles. Devaraj, Fan, and Kohli (2002) measure consumer satisfaction with the electronic commerce channel, and find that perceived ease of use and usefulness are important in forming consumer attitudes and satisfaction with the electronic commerce channel. They also find general support for consumer satisfaction as a determinant of channel choice preference. Also, satisfaction is strongly related to consumers' preference for the online channel (Devaraj, Fan, \& Kohli, 2006).

\section{Hypotheses}

According to Balasubramanian et al. (2005), this study considers five factors in the pursuing goals, which are economic goals, self-affirmation, symbolic meaning, socialization and experiential impact, and shopping schemas. Customers' objectives influence their choice of channels, and their objectives differ in various pursuing goals. Consequently, this study presents the conceptual model presented in Figure 1.

\subsection{Economic goals and product utility}

Neoclassical economists stress purely economic goals while consumers focus on maximizing net utility. Utility is defined as the satisfaction consumers derive from goods less the total costs of obtaining them which, apart from price, may include the real costs of travel, the opportunity cost of time, and the implicit cost of inconvenience (Balasubramanian, 1998). Expected utility theory states that decision makers choose between risky or uncertain prospects by com-

\section{〈Figure 1〉 Proposed Model}

\section{Pursuing goals}



Impact of Pursuing Goals on Customer Channel Preference: Mediating Effects of Product Utility and Process Utility 19 
paring their expected utility values (i.e., the weighted sums obtained by adding the utility values of outcomes multiplied by their respective probabilities) (Davis, Hands, \& Maki, 1997). Thus, expected utility is positively related to the utility value of outcomes. We can understand that when a customer's expected utility is high or low, his or her utility value of outcomes may be low or high even though the actual outcomes is high or low. Meanwhile, it can be understood that the expected economic goals as an expected value could decide the consumer's feelings towards outcomes. Therefore, we advance the following hypothesis.

Hypothesis 1: Customers' economic goals are positively related to product utility.

\subsection{Self-affirmation and product utility}

Self-affirmation theory proposes the existence of a self-system that serves to maintain a global image of self-integrity through frequent explanations and rationalizations to the self. Self-affirmation is closely related with the egobased view of dissonance (Spencer, Josephs, \& Steele, 1993: Steele, 1988, 1990; Steele \& Liu, 1983; Steele, Spencer, \& Lynch, 1993). This self-affirming, image-maintaining process is activated when an individual encounters information that threatens his or her positive view of self, and it is carried out until the threats are explained away and the individual's sense of overall adaptive and moral adequacy is restored (Heine \& Lebman, 1997). In selfperception theory, Bem (1972) suggests that individuals examine their own behavior and its attendant circumstances to determine their attitudes towards themselves. So we can infer that as persons affirm something, they would try their best to maintain their global image of these things, such as products they bought. If the products have some defects, they would persuade themselves until the defects are explained away whereas if the products they bought are satisfying, they would be proud of their behavior. Therefore, we hypothesize the following.

Hypothesis 2: Customers' self-affirmation is positively related to product utility.

\subsection{Symbolic meaning and product utility}

Longstanding findings from design, art, and advertising research indicate that visual elements such as shape, color, logo, and typeface are perceived not only in terms of their formal or technical properties but also in terms of the symbolic or affective connotations they embody (Rompay, Pruyn, \& Tieke, 2009). For instance, Zhang, Feick, \& Price (2006) show that rounded logos are generally perceived as more harmonious and less aggressive than angular logos. Likewise, Rompay, Hekkert, Saakes, and Russo (2005) demonstrate a relationship between a 
product's relative height and perceived dominance, explaining this finding in terms of the experiential; being in a high position is associated with greater control (e.g., visual control over those below) or power (e.g., objects are easier to manipulate from above). As illustrated by these examples, symbolic meanings come in different types; some (e.g., pride and dominance) are grounded in affective experiences arising from embodied interactions with the environment and may therefore be considered 'affective' or 'embodied.' Others involve cognitive evaluations (Lakoff \& Turner, 1989); typifying a product as modern or trendy, for instance, involves a cognitive comparison between the target product and other exemplars of the product category. Regardless of the type of symbolic meaning, on a more general level, symbolic meanings reflect those properties consumers discern in products that are not literally part of product appearance (cf. Blank, Massey, Gardner, \& Winner, 1984). With respect to brands, such meanings reflect symbolic brand characteristics that shape a brand's character or personality (Aaker, 1997), and the question becomes how such characteristics can be connoted through features of product design (Karjalainen, 2007).

Insights into the structural relations between visual elements and symbolic meanings are important. A considerable number of studies have demonstrated the increasing importance of symbolic meaning with respect to consumer decision-making (Bloch, 1995; Childers \& Jass, 2002; Creusen \& Schoormans, 2005; Karjalainen, 2007). For instance, Creusen, and Schoormans (2005) show that, apart from bringing aesthetic delight, for consumers the most important utility of a product's appearance is the portrayal of symbolic meaning. This importance of symbolic meaning can be understood, in part, by the notion that products are an important means for self-expression and identity formation (e.g., Belk, 1988). Therefore, we hypothesize as follows in $\mathrm{H} 3$.

Hypothesis 3: The symbolic meaning of the customer is positively related to product utility.

\subsection{Socialization and experiential impact and process utility}

Raghunathan and Corfman (2004) find that the perception of congruity between one's own opinions and those of others leads to positive feelings. They find that people generally desire the presence of others because it provides opportunities for creating and maintaining human bonds (which is a pleasurable experience) or enhancing the veridicality of one's opinions (which is a diagnostic tool for making better future decisions). Since during first meetings, two or more individuals typically engage in small and polite talk, strangers interacting are likely to express congruent opinions enhancing their enjoyment during shopping (Berger \& 
Calabrese, 1975). Interestingly, people do not need to converse with others to perceive interpersonal congruence in opinions; in the absence of information to the contrary, people tend to believe that others' opinions and attitudes are similar to their own (Goethals, Shelley, \& Frost, 1979). Thus, being in the presence of others, including strangers, may increase people's enjoyment of shared experiences even if they hold dissimilar opinions (Balasubramanian et al., 2005). Consequently, they choose procedures that they believe will promise them the best material outcomes. (Tyler, Huo, \& Lind, 1999). Therefore, process utility may be less important when people lack personal social experience with others (Sondak \& Tyler, 2003). However, most consumers (such as farmers buying fertilizer) have post-experience. The results of related studies (Tyler et al., 1999) support the suggestion that the psychology of preference and of evaluation for post-experience buyers differ from that of pre-experience buyers. Based on these results, we hypothesize that:

Hypothesis 4: Social Influence and Experiential Impact on customers are positively related to their process utility of using one product.

\subsection{Shopping schemas/scripts and process utility}

Bettman (1979) defines a schema as an organized pattern of expectations for a stimulus domain. Schemas facilitate top-down, conceptually driven processing; individuals applying schemas rely on preexisting knowledge rather than new information (Abelson, 1981). We can define a script as a schema characterized by temporal ordering of its component actions (Smith \& Houston, 1985).

By invoking schemas, consumers alter their responses to external stimuli that could influence their agendas, the constraints they use in selecting or eliminating choice alternatives (Balasubramanian et al., 2005). As Hauser (1986) demonstrated, different agendas lead to different choices. By invoking a schema, a consumer would likely activate an agenda that involves top-down, concept-driven processing, rather than bottom-up, data-driven processing. Such a consumer would have little opportunity to process information following a rigorous, algebraic model that requires evaluating the traits of all available alternatives in isolation and then combining those evaluations to obtain overall evaluations of the alternatives (Anderson, 1981).

Schemas and scripts can influence individual shopping rituals. For example, consider a busy family who shops at the local farmer's market every Saturday morning. This weekly outing gives the family members an opportunity to spend time together. Rook (1984, p. 282) notes that within a family such ritual practices cement relationships and foster joint participation in numerous household activities because a change in activities alters their feelings towards 
shopping. Therefore, we hypothesize as follows in $\mathrm{H} 5$.

Hypothesis 5: Customers' shopping schemas and scripts are positively related to their process utility of buying products.

\subsection{Product/process utility and customer channel choice/preference}

There is little literature focusing on the relationship between product or process utility and consumer purchase decision. Vijayasarathy (2002) reports the results of an empirical study that investigated differences between internet shopping intentions for products categorized by cost and tangibility, and shows that intentions to shop using the internet differ by the tangibility of the product. Thus, product characteristics can influence consumers' choice behavior even in the same channel. The literature identifies the three stages in consumers' channel choice process, and the relevance between them. During the first stage, consumers gather information about many products to form their consideration sets and may find the internet particularly useful. Researchers agree that informationsearch costs are generally lowest in online channels (Bakos, 1997; Peterson et al., 1997). But online channels suffer from a significant limitation, in that they represent product attributes in an impoverished fashion, while customers can potentially experience all sensory elements (Schmitt \& Simonson, 1997). When customers perceive experiential input as likely to increase confidence in their judgments, they may prefer traditional retail stores. However, studies suggest that two factors are likely to moderate this effect: (a) product category type, and (b) familiarity or expertise with the product category (Alba \& Hutchinson, 1987). With time and experience, though, some customers may be able to learn the consumption language that allows them to translate non-experiential information into experiential benefits (West, Brown, \& Hoch, 1997).

In the second stage, the objective is to select the product(s) that offer(s) maximum utility. Consumers are likely to use different decision rules or heuristics across these two stages (Raghunathan, 2004). Customers are likely to choose channels based on whether the product category is functional or hedonic. When the product category is largely hedonic or is both functional and hedonic, customers are likely to prefer the traditional retail stores for this stage, given the difficulty of translating representations of hedonic attributes into the associated experiential benefits (Balasubramanian et al., 2005).

The economic objective in the third stage of the purchase process (purchase) is to minimize transaction costs and maximize consumption utility. In this stage, the consumer exchanges money for the product. Because of its lower transaction costs and (potentially) lower pur- 
chase prices, the customer is likely to prefer the direct channel to the traditional retail channel (Balasubramanian et al., 2005).

Tyler et al. (1999) suggest that preference and choice should be viewed as reflecting different psychological processes. Bolton, Brandts, and Ockenfels (2000) found that procedural judgments shape choices in experimental bargaining games. Hollander \& Tyler (2003) likewise find that the willingness of each party to accept a negotiated agreement in economic negotiations is not only linked to the favorability of that agreement, but also to the fairness of the negotiation procedure by which it was determined (Chen, Brockner, \& Greenberg, 2003). More generally, people are found to more willingly accept market outcomes when they feel that markets function in ways that are consistent with the procedures (Fiske \& Tetlock, 1997; Frey \& Overholzer, 1997; Kahneman, Knetsch, \& Thaler, 1986; Sondak et al., 2003). Based on three experiments, Tyler (2006) finds that in each of these contexts process utility influences help-seeking choices. His findings suggest that people's utilities extend beyond financial and material resources, even in settings traditionally viewed as framed by economic outcomes. All of these findings suggest that process utility will be important in individual decision-making or purchase choice preference. So we assume the following.

Hypothesis 6: Product utility to customers is positively related to their purchase process utility.

Hypothesis 7: Product utility to customers is positively related to their channel preference.

Hypothesis 8: Purchase process utility to customers is positively related to their channel preference.

\section{Methodology}

\subsection{Research Procedure and Sample}

We conducted this study in the fertilizer industry in China, and targeted the survey at Chinese rural customers. This fertilizer market is very competitive, with a range of competing service providers. This study selected the fertilizer products of Chinese rural customers to investigate the hypotheses this research has raised. The targeted respondents for this study were buyers of fertilizer who are the decisionmakers in the selection and use of fertilizer for their farming operations.

The population we selected is the farmers who buy fertilizer products every year and live in East and Midwest China, such as Shandong, Anhui, Henan, Hebei, Shanxi, Hubei, Zhejiang, Yunnan or Tianjin. These provinces contain developed, developing, and under-developed regions, and each area has lots of farmers and various planting characteristics; therefore, they 
can be seen as an representative of China. Each respondent comes from different families that consist of 3-4 persons. Next, we selected 500 university students from different regions of China who are currently residing in Shandong province and whose parents or neighbors are eligible (farmers in the target areas mentioned above). Here we involved the university students in the survey to get reliable information about the respondents we want immediately. Therefore, we were able to focus on the target respondents quickly and gain their trust via their children to answer our questions in a serious manner. On the other hand, Chinese farmers seldom visit the internet, and therefore we could not email the surveys to collect data. Moreover, they do not adequately understand the professional functions of questionnaires due to limited education. Therefore, the involved university students were able to eliminate the worries.
Although the population of Chinese farmers is huge, we expected the characteristics of farmers' demand to be similar in the East and Midwest regions and the sample size of $500 \mathrm{re}^{-}$ spondents used in the survey was sufficient to adequately explain the issue. Then we gave the university students involved the questions and let them help us contact their parents to obtain answers from 500 different farmers.

Drawing on the knowledge about economic goals, self-affirmation, symbolic meaning, social influence and experiential impact, schemas and scripts, product utility, process utility, and channel choice from the literature, we developed a structured questionnaire to perform this investigation. Surveys were sent to the $500 \mathrm{se}^{-}$ lected families by the 500 university students from April 9 to May 8, 2013, and we received back 232 of the 500 questionnaires, and the response rate was $46.4 \%$. The detailed characteristics of the respondents are suggested in Table 1.

〈Table 1〉 Descriptive sample characteristics

\begin{tabular}{|c|c|c|c|c|c|}
\hline & Freq. & $\%$ & & Freq. & $\%$ \\
\hline Gender & & & Annual Income (¥) & & \\
\hline male & 130 & 56.03 & $10000-20000$ & 64 & 27.59 \\
\hline female & 102 & 43.97 & 20000-30000 & 95 & 40.95 \\
\hline Age & & & $30000-40000$ & 53 & 22.84 \\
\hline$>60$ & 37 & 15.95 & $>40000$ & 20 & 8.62 \\
\hline $45-60$ & 117 & 50.43 & Relational Duration & & \\
\hline $30-45$ & 78 & 33.62 & $1-5$ years & 56 & 24.14 \\
\hline Education Level & & & $5-10$ years & 66 & 28.45 \\
\hline elementary school & 67 & 28.88 & $>10$ years & 110 & 47.41 \\
\hline junior high school & 135 & 58.19 & Regions & & \\
\hline senior high school & 28 & 12.07 & East China & 129 & 55.60 \\
\hline college & 2 & 0.86 & Midwest China & 103 & 44.40 \\
\hline
\end{tabular}




\subsection{Measurement variables}

The survey was used to measure the economic goals, self-affirmation, symbolic meaning, social influence and experiential impact, schemas and scripts, product utility, process utility, and customer channel preference of farmers who need to buy fertilizer. Most of the instruments to measure the constructs in this paper come from previous literature in order to ensure content validity when adapting them to Chinese farmers in the fertilizer market. Respondents were asked to respond to a series of questions measured on a 7-point Likert-type scale.

The economic goals are drawn from the work of Balasubramanian (1998). Respondents were asked the (1) purchase price, (2) convenience of purchase, and (3) opportunity cost. To measure self-affirmation, four items used in Brown (1986), Cialdini et al. (1980), Heine \& Lebman (1997), Langer et al. (1975), Lund (1925), and Miller et al. (1975) were adapted: (1) encounter information, (2) choose a better brand, (3) satisfaction with the same fertilizer; (4) attribution of success to self and failure to others. Symbolic meaning was developed drawing on Aaker (1997), Karjalaine (2007), Lakoff \& Turner (1989), and Rompay et al. (2009)'s studies. The five items asked about were (1) visual elements such as shape, color, logo, and typeface; (2) affective experiences; (3) cognitive evaluations; (4) brand's character or personality; and (5) features of product design.
Balasubramanian et al. (2005), Berger et al. (1975), Goethals et al. (1979), Raghunathan \& Corfman (2004), and Tyler et al. (1999)'s studies were drawn on to develop a measure of social influence and experiential impact. Three 7-point Likert scales asked about (1) desiring the presence with others; (1) desiring the presence with others; (2) individuals interacting; and (3) believing others' similar opinions and attitudes. Schemas and scripts' two items were used to ask about (1) purchasing with other people, and (2) ordering time (Abelson, 1981; Bettman, 1979; Smith \& Houston, 1985).

The measures of product utility and process utility are drawn from the work of Brouwer et al. (2005), Davis et al. (1997), Donaldson et al. (1997), Patterson et al. (1997), and Tyler (2006). Respondents were asked to comment on product utility - (1) values of outcomes, (2) effect of product; (3) enough quality; and on process utility - (1) faster improvement (achievement), (2) shorter stay, (3) quicker return to other work. Finally, for customer channel preference, Bendapudi et al. (1997), Devaraj et al. (2002), and Wallace et al. (2004)'s scales were used. The participants were asked about (1) satisfaction and repurchase intentions, (2) channel preference and channel loyalty, and (3) switching cost. 


\section{Results}

\subsection{Reliability and validity analysis}

Cronbach's a was measured for all eight of the multiple item scales measured on the survey. As can be seen from Table 2, the loading value of each item is near or exceeds 0.7, and thus this result indicates a good fit to the data (Fornell \& Larcker, 1981). CR(composite reli- ability) and AVE(average variance extracted) of constructs are acceptable.

Confirmatory factor analysis (CFA) was conducted to assess the convergent validity of the scales. The overall factor loadings of all items were higher than 0.60 . The model's fit proved to be acceptable: $\chi^{2}=118.39$ (df $=51, P=$ $0.00), \mathrm{CFI}=0.92$, GFI $=0.92$, RMSEA $=$ $0.01, \mathrm{NFI}=0.88, \mathrm{RMR}=0.06 . \mathrm{AVE}$ values over or near 0.5 proved that the constructs used in this study had discriminant validity.

〈Table 2〉 Reliability of variables

\begin{tabular}{ccccc}
\hline Variables & \# of Items & Cronbach's a & CR & AVE \\
\hline Economic Goal & 3 & 0.60 & 0.75 & 0.51 \\
Self-affirmation & 4 & 0.72 & 0.78 & 0.47 \\
Symbolic meaning & 5 & 0.77 & 0.80 & 0.44 \\
Social influence and experiential impact & 3 & 0.70 & 0.73 & 0.48 \\
Schemas and scripts & 2 & 0.67 & 0.67 & 0.51 \\
Product utility & 3 & 0.71 & 0.75 & 0.51 \\
Process utility & 3 & 0.70 & 0.76 & 0.52 \\
Channel choice preference & 3 & 0.67 & 0.78 & 0.54 \\
\hline
\end{tabular}

〈Table 3〉 Correlation matrix

\begin{tabular}{lcccccccc}
\hline & $(1)$ & $(2)$ & $(3)$ & $(4)$ & $(5)$ & $(6)$ & $(7)$ & $(8)$ \\
\hline (1) Economic Goal & 1.00 & & & & & & & \\
(2) Self-affirmation & 0.19 & 1.00 & & & & & & \\
(3) Symbolic meaning & 0.31 & 0.22 & 1.00 & & & & & \\
(4) Social influence and experiential impact & 0.32 & 0.31 & 0.42 & 1.00 & & & & \\
(5) Schemas and scripts & 0.27 & 0.33 & 0.29 & 0.37 & 1.00 & & & \\
(6) Product utility & 0.24 & 0.22 & 0.39 & 0.35 & 0.16 & 1.00 & & \\
(7) Process utility & 0.29 & 0.16 & 0.28 & 0.33 & 0.18 & 0.40 & 1.00 & \\
(8) Channel choice preference & 0.17 & 0.14 & 0.32 & 0.34 & 0.27 & 0.19 & 0.39 & 1.00 \\
Mean & 4.44 & 3.47 & 4.19 & 4.26 & 4.05 & 4.51 & 4.57 & 4.13 \\
Standard deviation & 0.23 & 0.21 & 0.30 & 0.23 & 0.33 & 0.30 & 0.26 & 0.22 \\
\hline
\end{tabular}

* All intercorrelations are significant $(\mathrm{p}<.05)$ 
All correlation coefficients between constructs were less than 0.85, indicating good discriminant validity (Kline 1998).

\subsection{Hypothesis tests}

Then this study estimated the hypothesized relationships using structural equation modeling, and estimated the structural model using LISREL8.80 with the maximum likelihood estimation method. The results show that $\chi^{2}=$ 37.26, $\mathrm{df}=10, \mathrm{p}\langle 0.001$, IFI $=0.944>0.9$, $\mathrm{CFI}=0.943>0.9, \mathrm{GFI}=0.961>0.9, \mathrm{AGFI}$ $=0.860>0.8, \mathrm{NFI}=0.927>0.9, \mathrm{SRMR}=$ $0.0738<0.1$ ( Hu \& Bentler, 1999), RMSEA = 0.110. Thus, the overall goodness of fit statistics show that the structural model fits the data well, except RMSEA. The root mean square error of approximation (RMSEA) is 0.110. In general, to satisfy the criteria for a good model, the RMSEA should be less than 0.08 (Jarvenpaa \&Tractinsky, 2000). Actually, the main cause is that $\chi^{2} / \mathrm{df}=3.726>3$, and the standard from Hayduk (1988) is less than 3, but Bollen (1989) and Hair, Anderson, Tatham, \&Black (1998) indicate that $\chi^{2} / \mathrm{df}<5$ is feasible. Therefore, the RMSEA for this construct was generously acceptable considering the large number of items and factors (Byrne, 2009).

This study tests the hypotheses based on the results provided in the proposed model. Hypothesis 1 indicates that farmers' economic goals are related to fertilizer utility. Hypothesis 1 is mar- ginally supported $(\gamma=0.12, \mathrm{t}=1.74, \mathrm{p}<.10)$. Hypothesis 2 indicates that farmers' selfaffirmation is related to their product utility. Hypothesis 2 is marginally supported ( $\gamma=0.14$, $\mathrm{t}=1.96, \mathrm{p}<.10)$. Table 4 reports the standardized path coefficients for the estimated relationships. Hypothesis 3's prediction that symbolic meaning for farmers is positively $\mathrm{re}^{-}$ lated to fertilizer utility is supported ( $\gamma=0.29$, $\mathrm{t}=5.18, \mathrm{p}<.01)$. Hypothesis 4 predicting that social influence and experiential impact for farmers are positively related to their process utility of using fertilizer is supported $(\gamma=0.15$, $\mathrm{t}=2.97, \mathrm{p}<.05)$. Hypothesis 6 expects that fertilizer utility to farmers is positively related to their purchase process utility. In the current literature, few study focuses on the relationship between product utility and process utility, and its effects on marketing channel, including in the qualitative and quantitative analyses. The tested result of this study indicates that hypothesis 6 is supported $(\gamma=0.28, t=0.83, p<$ .01). As this study expected, hypothesis 8's prediction is supported. Hypothesis 8 indicates that purchase process utility to farmers is positively related to their channel choice preference $(\gamma=0.34, t=5.28, p<.01)$.

However, hypothesis 5 's prediction that customers' shopping schemas and scripts are positively related to their process utility of buying products is not supported $(\gamma=0.05, \mathrm{t}=0.63, \mathrm{p}$ $>0.1$ ). In general, suitable shopping schemas/ scripts can bring customers better purchase 
experiences, further they can feel high process utility (Bettman, 1979; Smith \& Houston, 1985). But fertilizer, as a kind of capital good, differs from other general products. As a farmer, anyone should prefer to get more return at a lower cost over enjoying a ritual of buying. Therefore, suppliers need not consider farmer's utilitarianism or hedonism pursuits. Its ultimate causes emerge from pursuing utilitarianism (Zhou \& Poppo, 2010). Hypothesis 7's prediction is not supported $(\gamma=0.03, t=5.62, p$ $>0.1)$. It is certain that the same product marketed by different channels has almost the same product utility; therefore, customers will be challenged to identify which channel is better if they focus only on the product itself.

\section{Discussion and Implications}

\subsection{Discussion}

This study tests the relationship between customers' economic-social-psychological pursuing goals and customer channel choice decisions, and explores how pursuing goals can impact customer channel preference by mediating the variables of product utility and process utility. Research questions in this study include: how will customers' economic goals, selfaffirmation, and symbolic meaning impact their product utility; how will customers' social in- fluence/experiential impact and shopping schemas/scripts affect their process utility; how will product utility impact on process utility; and how will product/process utility influence customer channel choice preference. Based on the data analysis, we find that a) farmer's economic goals are positively related to product utility, b) customers' self-affirmation is related to product utility, c) symbolic meaning for farmers is positively related to product utility, d) social influence and experiential impact for farmers are positively related to their process utility of buying products, e) product utility to farmers is positively related to their purchase process utility, f) purchase process utility to farmers is positively related to their channel choice preference. But the result does not support that a) customers' shopping schemas and scripts are related to product utility, or b) the product utility is related to customer channel choice preference.

The results show that product utility and process utility can mediate the relationship between the pursuing goals and customer channel preference positively. Consequently, we can conclude that customers' economic-socialpsychological pursuing goals can directly influence customer channel preference via their purchase process utility and product utility. This result also implies that product utility is effective on process utility during consumer's buying decision making, and process utility and product utility are not mutually independent. 
〈Table 4〉 Results of hypothesis tests

\begin{tabular}{clccc}
\hline Hypothesis & \multicolumn{1}{c}{ Path } & Estimate & T-value & Result \\
\hline H1 & Economic Goal $\rightarrow$ Product utility & 0.12 & $1.74^{+}$ & Supported \\
H2 & Self-affirmation $\rightarrow$ Product utility & 0.14 & $1.96^{+}$ & Supported \\
H3 & Symbolic Meaning $\rightarrow$ Product utility & 0.39 & $5.18^{* *}$ & Supported \\
H4 & Social Influence \& Experiential Impact $\rightarrow$ Process utility & 0.20 & $2.97^{*}$ & Supported \\
H5 & Schemas and Scripts $\rightarrow$ Process utility & 0.05 & 0.83 & Not Supported \\
H6 & Product utility $\rightarrow$ Process utility & 0.28 & $5.28^{* *}$ & Supported \\
H7 & Product utility $\rightarrow$ Customer channel choice preference & 0.03 & 0.63 & Not Supported \\
H8 & Process utility $\rightarrow$ Customer channel choice preference & 0.34 & $5.62^{* *}$ & Supported \\
\hline
\end{tabular}

Note: ${ }^{+} \mathrm{p}<0.1,{ }^{*} \mathrm{p}<0.01,{ }^{* *} \mathrm{p}<0.001$

Therefore, purchase process utility is a "latent driving force" on customer's channel choice decision.

\subsection{Theoretical implications}

This study has several theoretical implications. First, this study empirically tests the structural model of Balasubramanian et al. (2005) in a different research setting. In their study, they analyze the relationship between the pursuit of goals and customer channel choice preference by qualitative research. This study demonstrates these relationships using structural equation modeling.

Second, this study finds that product utility can mediate the relationship between the pursuing goals and customer channel choice preference indirectly by process utility, while process utility can do so directly. In most existing marketing channel literature, the authors focus their targets on customer satisfaction, loyalty, value, intention, motivation, etc., but few researchers pay attention to the causes that lead to or accelerate those psychological behaviors; empirical studies to verify those processes are even scarcer.

Moreover, this study argues that product utility positively relates to process utility during customers' buying process. In the existing psychological literature, the researchers demonstrate the existence of process utility (Donaldson, \& Shackley, 1997) and suggest that it derives from both the outcomes of service and the process of providing service in the health re- $^{-}$ search domain (Brouwer et al., 2005). The results of those studies imply that product utility not only supplies the outcomes to customers directly, but also effects customers' process utility. Therefore, product utility can positively influence customers' outcomes, and further customers' decision making. But this study verifies that product utility does not impact the customer's channel preference decision directly, 
while process utility mediates the link between product utility and customer channel preference.

\subsection{Managerial implications}

We can draw several managerial implications from this study. First and most importantly, process utility plays a remarkably strong role in influencing the customer channel preference context. Therefore, agricultural capital goods suppliers must pay attention to customer process utility control and put a lot of effort into creating high quality buying process utility. This study particularly suggests that social influence and experiential impact on customers is a crucial factor in building a supplier's customer base, because the link between social influence/ experiential impact on customers and customers' buying process utility is remarkably supported in this study. A high social influence and experiential impact on customers is the most important factor leading to future business, as well as encouraging existing customers to provide positive word of mouth and to appreciate having the buyer - supplier relationship. Therefore, good investments in social influence and experiential impact on customers will essentially enhance the quality of the buyersupplier relationship.

Second, the results of this study suggest that the link between product utility and customer channel preference is positively related. Consequently, this finding shows the importance of economic goals, self-affirmation, and symbolic meaning. Agricultural capital goods suppliers should pay attention to understand customers' economic goals, self-affirmation, and symbolic meaning better and to create good product utility for existing and potential customers.

Third, to understand customer perception of utility, this research provides management with the ability to map out a typology of utility through the use of the available composite measures of utility, product utility, and process utility. The typology was introduced by Balasubramanian et al. (2005). Agricultural capital goods suppliers are likely to be able to manage their customers more effectively by segmenting their customer base according to customers' levels of two aspects of utility. The classification system can also be useful to marketers as they try to develop utility. Marketers should identify groups of customers based on which utility they prefer and develop strategies for existing products and services. This study reinforces the importance of the two components of utility to customer channel preference and illustrates that, while both are important in customers' channel choice decision, different contents are applied to develop each component.

Overall, to confirm customer channel choice decision with the supplier, a supplier should understand all five aspects of the pursuing goals which are economic goals, self-affirmation, symbolic meaning, social influence/experiential impact, and shopping schemas/scripts. 
Specifically, in order to understand customers' economic goals, a supplier should focus on purchase convenience and additional discount or extra benefit. In efforts to emphasize self-affirmation, a supplier should focus on customer satisfaction. Satisfaction appears to be a crucial factor in maintaining customer affirmation. For symbolic meaning, a supplier should pay attention to its product advantage and brand character. In order to enhance social influence/experiential impact, a supplier should invest more in wordof-mouth. In regard to shopping schemas/scripts, a supplier should study neighboring groups and their purchase decisions.

\subsection{Limitations of the research and methodological implications}

This study has several limitations that suggest future research directions. First, the data in this study is from the fertilizer industry, which may limit its generalization to other industries. The study sampled only Chinese farmers. Because farmers are of different sizes and characteristics compared to larger corporate customers, we cannot generalize their buying behavior and attitudes to the whole population of fertilizer buyers. The buyer behavior of larger fertilizer buyers may be different from the buyer behavior of Chinese farmers.

Second, this study suggests the need for further investigation into the relationship between product utility and process utility. Since prod- uct utility positively relates to process utility, the intrinsic relationship principle should be studied in future research.

Third, this study does not investigate the relationship among economic goals, self-affirmation, symbolic meaning, and process utility; nor social influence and experiential impact, schemas and scripts, or product utility. Future research designs should consider including details of the relationship among economic goals, selfaffirmation, symbolic meaning, and process utility, and among social influence and experiential impact, schemas and scripts, and product utility.

〈Received February 28. 2014〉

〈Revised July 19. 2014〉

$\langle$ Accepted July 25. 2014〉

\section{References}

Aaker, J.L. (1997). "Dimensions of brand personality," Journal of Marketing Research, 34 (3), 347-356.

Abelson, R.P. (1981). "Psychological status of the script concept," American Psychologist, 36 (7), 715-729.

Alba, J., \& W.J. Hutchinson (1987), “Dimensions of consumer expertise," Journal of Consumer Research, 13 (4), 411-454.

Alba, J., J. Lynch, B. Weitz, C. Janiszewski, R. Lutz, \& A. Sawyer (1997). "Interactive home shopping: consumer, retailer, and 
manufacturer incentives to participate in electronic marketplaces," Journal of Marketing, 61 (3), 38-53.

Arnheim, R. (1974). "Art and visual perception: A psychology of the creative eye," Berkeley, CA: University of California Press.

Aspinwall, L. (1962), The characteristics of goods theory, in William, V., Kelley, E.J. (Eds),Managerial Marketing, Perspectives and Viewpoints, Irwin, Homewood, IL.

Bagozzi, R.P. \& P.R. Warshaw (1990). “Trying to consume," Journal of Consumer Research, 17(2), 127-140.

Bakos, Y. (1997). "Reducing buyer search costs: Implications for electronic market-places," Management Science, 43 (12), 1676-1692. Balasubramanian, S. (1998). "Mail versus mall: A strategic analysis of competition between direct marketers and conventional retailers," Marketing Science, 17(6), 181-195. Balasubramanian, S., R. Raghunathan, \& V. Mahajan (2005). "Consumers in a multichannel environment: Product utility, process utility, and channel choice," Journal of Interactive Marketing, 19 (2), 12-30.

Bar, M., \& M. Neta (2006). "Humans prefer curved visual objects," Psychological Science, 17 (8), 645-648.

Belk, R.W. (1988). "Possessions and the extended self," Journal of Consumer Research, 15 (2), 139-167.

Bem, D.J. (1972). “Self-perception theory,” In
L. Berkowitz (Ed.), Advances in Experimental Social Psychology (pp. 1-62). New York: Academic Press.

Berger, C.R., \& R.J. Calabrese (1975). "Some explorations in initial interaction and beyond: toward a developmental theory of interpersonal communication," Human Communication Research, 1 (2), 99-112.

Berman, B. (1996). Marketing channels, Wiley, New York, NY.

Bettman, J.R. (1979). “An information processing theory of consumer choice," Reading, MA: Addison-Wesley.

Blank, P., C. Massey, H .Gardner, \& E. Winner (1984). "Perceiving what paintings express," In W. R. Crozier \& A. J. Chapman (Eds.), Cognitive processes in the perception of art (pp. 127-143). Amsterdam: North Holland. Bloch, P.H. (1995). "Seeking the ideal form: Product design and consumer response," Journal of Marketing, 59 (3), 16-29.

Bollen, K.A. (1989). "Structural equations with latent variables," Wiley, New York.

Bolton, G.E., J. Brandts, \& A. Ockenfels (2000). "Fair procedures: Evidence from games involving lotteries," Unpublished manuscript. Department of Management Sciences. Pennsylvania State University.

Brouwer, W. B., Exel, N., Berg, B. V. D., Bos, G. A., \& Koopmanschap, M. A. (2005). Process utility from providing informal care: the benefit of caring. Health Policy, 74(1), 85-99. 
Brown, J.D. (1986). "Evaluations of self and others: Self-enhancement biases in social judgments," Social Cognition, 4 (4), 353-376.

Byrne, B. M. (2009). "Structural equation modeling with AMOS: Basic concepts, applications, and programming," CRC Press.

Chen, Y., J. Brockner, \& J. Greenberg (2003). "When is it 'a pleasure to do business with you?' The effects of relative status, outcome favorability, and procedural fairness," Organizational Behavior and Human Decision Processes, 92 (1/2), 1-21.

Childers, T.L., \& J.F. Jass (2002). “All dressed up with something to say: Effects of typeface semantic associations on brand perceptions and consumer memory," Journal of Consumer Psychology, 12 (2), 93-106.

Cialdini, R.B., \& K.D. Richardson (1980). "Two indirect tactics of image management: Basking and blasting," Journal of Personality and Social Psychology, 39 (3), 406-415.

Cohen, I.R. (1967). "Natural and Immune Human Antibodies Reactive with Antigens of Virulent Neisseria gonorrhoeae: Immunoglobulins G, M, and A," Journal of Bacteriology, 94 (1), 141-148.

Creusen, M.E.H., \& J.P.L. Schoormans (2005). "The different roles of product appearance in consumer choice," Journal of Product Innovation Management, 22 (1), 63-81.

Davis, J., W.Hands, \& U.Maki (1997). "Handbook of Economic Methodology," London,
Edward Elgar, 342-350.

Devaraj, S., Fan, M., \& Kohli, R. (2006). "Examination of online channel preference: using the structure-conduct-outcome framework," Decision Support Systems, 42 (2), 1089-1103.

Devaraj, S., M. Fan, \& R. Kohli (2002). “Antecedents of B2C channel satisfaction and preference: Validating e-commerce metrics," Information Systems Research, 13(3), 316333.

Donaldson, C. \& P. Shackley (1997). “Does "process utility" exist? A case study of willingness to pay for laparoscopic cholecystectomy," Social Science \& Medicine, 44 (5), 699-707.

Engel, J.F., R.D. Blackwell, P.W. Miniard (1990). Consumer behaviour, Dryden, Chicago, IL. Fishbach, A. \& J. Choi (2012). "When thinking about goals undermines goal pursuit," Organizational Behavior and Human Decision Processes. 118 (2), 99-107.

Fiske, A.P., \& P. Tetlock (1997). "Taboo tradeoffs: Reactions to transactions that Transgress the spheres of justice," Political Psychology, 18 (2), 255-297.

Fornell, C., \& D.F. Larcker (1981). "Evaluating structural equation models with unobservable variables and measurement error," Journal of Marketing Research, 18 (1), 3950.

Frey, B.S., \& G.F. Overholzer (1997). "The cost of price incentives: An empirical an- 
alysis of motivation crowding-out," American Economic Review, 87 (4), 746-755.

Gensler, S., M.G. Dekimpe, \& B. Skiera (2007). "Evaluating channel performance in multi-channel environments," Journal of Retailing and Consumer Services, 14 (1), 17-23.

Goethals R.G., J.A. Shelley, \& M. Frost (1979). "Perceptions of the magnitude and diversity of social support," Journal of Experimental Social Psychology. 15 (6), 570-581.

Greenwald, A.G., F.S. Bellezza, \& M.R. Banaji (1988). "Is self-esteem a central ingredient of the self-concept?" Journal of Personality and Social Psychology, 14 (1), 34-45.

Hair, J.F., R.E. Anderson, R.L. Tatham, W.C. Black (1998). "Multivariate Data Analysis," $5^{\text {th }}$ Edition, Prentice Hall, New Jersey.

Harding, J., A. Popplewell, K. Fung, Y.K. Richard, A.R. Omar (2001). "An intelligent information framework relating customer requirements and product characteristics," Computers in Industry, 44 (1), 51-65.

Hauser, (1986). "Notes on the distribution of schooling in the black population," Working Paper, No. 86-8. Madison: Center for Demography and Ecology, University of Wisconsin.

Hayduk, L. A. (1988). "Structural equation modeling with LISREL: Essentials and advances," JHU Press.

Heath, C., R. Larrick, \& G. Wu (1999). "Goals as reference points," Cognitive Psychology, 38 (1), 79-109.

Heine, S.J. \& D.R. Lebman (1997). "Culture, dissonance and self-affirmation," Personality and Social Psychology Bulletin, 23 (4), 389-400.

Higgins, E.T. (1987). "Self-discrepancy: A theory relating self and affect," Psychology Review, 94 (3), 319-340.

Hollander B.R., \& T.R. Tyler (2003). "Do nice people finish last? Procedural justice in economic negotiations," Unpublished manuscript, Law School, New York University.

Hu, L. T., \& Bentler, P. M. (1999). "Cutoff criteria for fit indexes in covariance structure analysis: Conventional criteria versus new alternatives," Structural Equation Modeling: A Multidisciplinary Journal, 6 (1), 1-55.

Huffman, C \& MJ. Houston (1993). "Goaloriented experiences and the development of knowledge," Journal of Consumer Research, 20 (2), 190-207.

Jarvenpaa. S.L. \& Tractinsky N. (2000). Consumer trust in an internet store. Information Technology \& Management 1(1), 45-71.

Kahneman, D., J.L. Knetsch, \& R.H. Thaler (1986). "Fairness as a constraint on profit seeking: Entitlements in the market," American Economic Review, 76 (4), 728741.

Karjalainen, T. (2007). "It looks like a Toyota: Educational approaches to designing for 
visual brand recognition," International Journal of Design, 1 (1), 67-81.

Lakoff, G., \& M. Turner (1989). "More than cool reason: A field guide to poetic metaphor," Chicago: University of Chicago Press.

Langer, E.J., \& Roth, J. (1975). "Heads I win, tails it's chance: The illusion of control as a function of sequence of outcomes in a purely chance task," Journal of Personality and social Phychology, 32 (2), 951-955.

Li, Dao-sheng, and Jinhwan Hong (2013). "Development of a new direct marketing channel in the Chinese rural market: The case of Hongfu fertilizer company," Asia Marketing Journal, 15 (2), 29-47.

Lund, F.H. (1925). "The psychology of belief: A study of its emotional and volitional determinants," Journal of Abnormal and Social Psychology, 20 (2), 63-81.

Miller, D.T., \& Ross, M. (1975). "Self-serving biases in the attribution of causality: Fact or fiction?" Psychological Bulletin, 82 (2), 213-225.

Oppewal, H., Tojib, D. R., \& Louvieris, P. (2013). "Experimental analysis of consumer channel-mix use," Journal of Business Research, 66 (11), 2226-2233.

Peterson, R.A., S. Balasubramanian, \& B.J. Bronnenberg (1997). "Exploring the Implications of the Internet for Consumer Marketing," Journal of the Academy of Marketing Science, 25 (4), 329-346.
Raghunathan, R. (2004). "Stage of Purchase Decision as a Determinant of Decision Rules," Working Paper, The University of Texas at Austin, Austin, TX.

Raghunathan, R., \& K.P. Corfman (2004). "Is Happiness Shared Doubled and Sadness Shared Halved?: Social Influence on Enjoyment of Pleasant and Unpleasant Experiences," Working Paper, The University of Texas at Austin, Austin, TX.

Rangan, V., E. Corey, F. Cespedes (1993). "Transaction cost theory: inferences from clinical field research on downstream vertical integration," Organization Science, 4 (3), 454-477.

Rompay, T.J.L., A.T.H. Pruyn, \& P. Tieke (2009). "Symbolic meaning integration in design and its influence on product and brand evaluation," International Journal of Design, 3 (2), 19-26.

Rompay, T.J.L., P. Hekkert, D. Saakes, \& B. Russo (2005). "Grounding abstract object characteristics in embodied interactions," Acta Psychologica, 119 (3), 315-351.

Rook, D.W. (1984). "Ritual Behavior and Consumer Symbolism," In T.F. Kinnear (Ed.), Advances in Consumer Research (Vol. 11, pp. 279-284). Provo, UT: Association for Consumer Research.

Schmitt, B., \& A. Simonson (1997). "Marketing Aesthetics,"New York: The Free Press.

Smith, R.A., \& M.J. Houston (1985). “A psychometric assessment of measures of 
scripts in consumer memory," Journal of Consumer Research, 12 (2), 214-224.

Sondak, H., \& T.R. Tyler (2003). "What should not money buy: The psychology of preferences for resource allocation procedures in groups," Unpublished manuscript, School of Business, University of Utah.

Spencer, S.J., R.A. Josephs, \& C.M. Steele, (1993). "Low self-esteem: The uphill struggle for self-integrity," In R. Baumeister (Ed.), New York: Plenum, 201-218.

Steele, C.M. (1988). "The psychology of selfaffirmation: Sustaining the social psychology," San Diego, CA: Academic Press, Vol.21, 261-302.

Steele, C.M. (1990). "Protecting the self: Implications for social psychology theory and minority achievement," Paper presented at the American Psychology Association Meeting, Boston, MA.

Steele, C.M., \& T.J. Liu (1983). "Dissonance processes self-affirmation," Journal of personality and Social Psychology, 45 (1), 5-19.

Steele, C.M., S.J. Spencer, \& M. Lynch (1993). "Self-image resilience and dissonance: The role of affirmational resources," Journal of Personality and Social Psychology, 64 (6), 885-896.

Trope, Y. (1975). "Seeking information about one's own ability as a determinant of choice among tasks," Journal of Personality and Social Psychology, 32 (6), 1004-1013.
Tyler, T.R. (2006). "Process utility and help seeking: What do people want from $\mathrm{ex}^{-}$ perts?" Journal of Economic Psychology, 27 (3), 360-376.

Tyler, T.R., Huo, Y.J., \& Lind, E.A. (1999). "The two psychologies of conflict resolution: Differing antecedents of pre-experience choices and post-experience evaluations," Group Processes \& Intergroup Relations, 2 (2), 99-118.

Verhoef, P.C., S.A. Neslin, \& B. Vroomen (2007). "Multichannel customer management: understanding the research-shopper phenomenon," International Journal of Research in Marketing, 24 (2), 129-148.

Vijayasarathy, L.R. (2002). "Product characteristics and Internet shopping intentions," Internet Research, 12 (5), 411-426.

West, P.M., C.L. Brown, \& S.J. Hoch (1997). "Consumption Vocabulary and Preference Formation," Journal of Consumer Research, 23 (2), 120-135.

Zhang, Y., L. Feick, \& L.J. Price, (2006). "The impact of self-construal on aesthetic preference for angular versus rounded shapes," Personality and Social Psychology Bulletin, 32 (6), 794-805.

Zhou, K.Z., \& L. Poppo (2010). "Exchange hazards, relational reliability, and contracts in China: The contingent role of legal enforceability," Journal of International Business Studies, 41 (5), 861-881. 


\section{〈Appendix 1〉 Measurement items}

\begin{tabular}{|c|c|c|}
\hline Factors & Items & Source \\
\hline $\begin{array}{c}\text { Economic } \\
\text { Goal }\end{array}$ & $\begin{array}{l}\text { 1. Focus on purchase price of fertilizer. } \\
\text { 2. Focus on convenience of purchasing fertilizer. } \\
\text { 3. Purchasing fertilizer would lose your other chances of making money. }\end{array}$ & Balasubramanian, 1998 \\
\hline Self-affirmation & $\begin{array}{l}\text { 1. During purchasing fertilizer, when you encounter information that } \\
\text { threatens your positive view of self, and it is carried out until the } \\
\text { threats are explained away and others consider you are write. } \\
\text { 2. You always consider the fertilizer you purchased is better than the } \\
\text { different brands bought by others. } \\
\text { 3. You are more satisfied than others around you to buy the same } \\
\text { fertilizer. } \\
\text { 4. If the fertilizer you bought is good, you will attribute the success to } \\
\text { yourself, on the contrary, you will attribute failure to others. }\end{array}$ & $\begin{array}{l}\text { Heine \& Lebman, } 1997 \\
\text { Brown, } 1986 \\
\text { Miller et al., } 1975 \\
\text { Cialdini et al., } 1980 \\
\text { Lund, } 1925 \\
\text { Langer et al., } 1975\end{array}$ \\
\hline $\begin{array}{l}\text { Symbolic } \\
\text { Meaning }\end{array}$ & $\begin{array}{l}\text { 1. Focus on the visual symbol, such as shape, color, mark, typeface, } \\
\text { during purchasing fertilizer. } \\
\text { 2. When you buy fertilizer, you tend to purchase the brand that you } \\
\text { loving. } \\
\text { 3. You will compare the fertilizer you want to buy with other fertilizer } \\
\text { when you purchasing fertilizer. } \\
\text { 4. When you buy fertilizer, you will consider the brand character. } \\
\text { 5. When you buy fertilizer, you will consider the product's design } \\
\text { characteristics, such as color, granular size, and shape. }\end{array}$ & $\begin{array}{l}\text { Rompay et al., } 2009 \\
\text { Lakoff \& Turner, } 1989 \\
\text { Aaker, } 1997 \\
\text { Karjalainen, } 2007\end{array}$ \\
\hline $\begin{array}{l}\text { Social Influence } \\
\text { and } \\
\text { Experiential } \\
\text { Impact }\end{array}$ & $\begin{array}{l}\text { 1. You like to buy fertilizer with other persons together, because they } \\
\text { can provide you some advice to enhance your purchase. } \\
\text { 2. During buying fertilizer, your view that interacts with other's can } \\
\text { accelerate your purchase. } \\
\text { 3. In the absence of information to purchase fertilizer, you tend to } \\
\text { believe that others' opinions and attitudes are similar to their own. }\end{array}$ & $\begin{array}{l}\text { Raghunathan \& } \\
\text { Corfman, } 2004 \\
\text { Berger et al., } 1975 \\
\text { Goethals et al., } 1979 \\
\text { Balasubramanian et al., } \\
2005 \\
\text { Tyler et al., } 1999\end{array}$ \\
\hline $\begin{array}{l}\text { Schemas and } \\
\text { Scripts }\end{array}$ & $\begin{array}{l}\text { 1. You like to purchase fertilizer with other persons who live around } \\
\text { you. } \\
\text { 2. In general, you buy fertilizer in a fixed period of time. }\end{array}$ & $\begin{array}{l}\text { Bettman, } 1979 \\
\text { Abelson, } 1981 \\
\text { Smith \& Houston, } 1985\end{array}$ \\
\hline Product Utility & $\begin{array}{l}\text { 1. Focus on the quantity of the fertilizer you bought is enough or not. } \\
\text { 2. Focus on the convenience during using the fertilizer that you bought. } \\
\text { 3. Focus on the farm pollution from the fertilizer you bought. }\end{array}$ & Davis et al., 1997 \\
\hline Process Utility & $\begin{array}{l}\text { 1. Faster transaction when you buy fertilizer. } \\
\text { 2. Shorter stay during your purchasing fertilizer. } \\
\text { 3. Quicker return to other work after buying fertilizer. }\end{array}$ & $\begin{array}{l}\text { Tyler, } 2006 \\
\text { Donaldson et al., } 1997 \\
\text { Brouwer et al., } 2005 \\
\text { Patterson et al.,1997 }\end{array}$ \\
\hline $\begin{array}{c}\text { Channel Choice } \\
\text { Preference }\end{array}$ & $\begin{array}{l}\text { 1. You are satisfied with fertilizer company's sales method. } \\
\text { 2. You are satisfied with the promotion, price, and service of fertilizer } \\
\text { company. } \\
\text { 3. It will bring you more risk if you transfer to buy other company's } \\
\text { fertilizer from a fixed seller. }\end{array}$ & $\begin{array}{l}\text { Devaraj et al., } 2002 \\
\text { Wallace et al., } 2004 . \\
\text { Bendapudi et al., } 1997\end{array}$ \\
\hline
\end{tabular}

